\title{
Lipopolysaccharides of Xenorhabdus nematophilus (Enterobacteriaceae) and Their Haemocyte Toxicity in Non-immune Galleria mellonella (Insecta: Lepidoptera) Larvae
}

\author{
By GARY B. DUNPHY*† AND JOHN M. WEBSTER \\ Department of Biological Sciences, Simon Fraser University, Burnaby, Vancouver, \\ Canada V5A 1 S6
}

(Received 27 July 1987; revised 11 December 1987)

\begin{abstract}
Three varieties of Xenorhabdus nematophilus subsp. nematophilus released lipopolysaccharide (LPS) during bacteraemia in larval Galleria mellonella. Larval serum triggered release of LPS from the bacterial envelope. LPS activated the plasmatocytes and eventually damaged the haemocytes. LPS and its lipid A portion bound to the insect haemocytes through D-glucosaminebinding lectins on the haemocyte surfaces. The toxicity of LPS resides in the fatty acids of the lipid A moiety.
\end{abstract}

\section{INTRODUCTION}

Xenorhabdus nematophilus, a mutualistic associate of the entomoparasitic nematode Steinernema feltiae, is voided by its nematode vector into the haemolymph of insects which the nematode has entered (Poinar \& Himsworth, 1967). Greater wax moth (Galleria mellonella) larvae respond to bacteria in the haemolymph by nodulation and phagocytosis mediated by haemocytes called granular cells and plasmatocytes (Ratcliffe \& Rowley, 1979). X. nematophilus subsp. nematophilus var. dutky is removed from the $G$. mellonella haemolymph by nodulation after modification of the bacterial cell envelope by the haemolymph (Dunphy \& Webster, 1984). $G$. mellonella similarly removes $X$. nematophilus subsp. nematophilus var. mexicanus from the haemolymph immediately after its injection, and these bacteria damage the granular cells and plasmatocytes by reproducing in or on them, before re-entering the haemolymph (Dunphy \& Webster, 1986). The unidentified damaging agent does not require concurrent bacterial metabolism for its release into the haemolymph, which implies that a structural component of the bacterial envelope is probably involved (Dunphy \& Webster, 1984). Kamionek (1975) and Seryczynska \& Kamionek (1977) showed that lipopolysaccharides from an unidentified subspecies of $X$. nematophilus elevated $G$. mellonella haemocyte counts, and this elevation has been associated with the occurrence of haemocyte damage (Dunphy \& Webster, 1984). However, until now there has been no proof of lipopolysaccharide release from $X$. nematophilus in $G$. mellonella haemolymph or of its mode of action.

Toxins produced by Gram-negative insect-pathogenic bacteria in vitro are assumed to be factors associated with the virulence of these bacteria in vivo (Lysenko, 1976). However, there are few reports of bacterial toxin production in vivo in non-immune insects. Ratcliffe \& Walters (1983) and Walters \& Ratcliffe (1983) attributed the destruction of nodules containing Bacillus cereus in the haemocoel of $G$. mellonella larvae to the metabolism of these virulent bacteria. Horohov \& Dunn (1984) detected, in the haemolymph of Manduca sexta infected with Pseudomonas aeruginosa 11-1A, a cytotoxin that induced vacuoles in the haemocytes; but the toxin appeared too late in the infection to be the cause of bacteraemia.

$\dagger$ Present address: Department of Entomology, Macdonald College, McGill University, St. Anne de Bellevue, Quebec H9X 1C0, Canada. 
The objectives of the present study were to identify a haemocytotoxin produced by $X$. nematophilus subsp. nematophilus varieties in larval G. mellonella and to propose a model for the mode of action of the toxin on larval haemocytes.

\section{METHODS}

Cultures and media. X. nematophilus subsp. nematophilus vars dutky, breton and mexicanus were isolated from Thimersol $(0.1 \%, \mathrm{w} / \mathrm{v} ;$ Sigma) surface-sterilized, dauer juvenile stages of the DD136, breton and mexican strains, respectively, of the entomophilic nematode Steinernema feltiae (Dunphy \& Webster, 1984). The bacteria were routinely subcultured at $27^{\circ} \mathrm{C}$ on Tergitol-7 agar (Difco) containing 2,3,5-triphenyltetrazolium chloride (30 mg $1^{-1}$ ) (Akhurst, 1980).

Bacillus subtilis (ATCC 6051) and Proteus vulgaris 11-1A were maintained on trypticase soy agar (Difco) at $27^{\circ} \mathrm{C}$ and subcultured at $7 \mathrm{~d}$ intervals.

For experimental purposes $24 \mathrm{~h}$ bacterial cultures were grown in LB-broth (Bertani, 1951) for $24 \mathrm{~h}$ at $27^{\circ} \mathrm{C}$ on a horizontal, gyrotary shaker $\left(150 \mathrm{r}\right.$.p.m.). The bacteria were centrifuge-washed $\left(5000 \mathrm{~g}, 10 \mathrm{~min}, 10^{\circ} \mathrm{C}\right)$ three times in phosphate-buffered saline (PBS: $137.9 \mathrm{mM}-\mathrm{NaCl}, 2.7 \mathrm{~mm}-\mathrm{KCl}, 8.1 \mathrm{~mm}-\mathrm{Na}_{2} \mathrm{HPO}_{4}, 1.5 \mathrm{~mm}-\mathrm{KCl}, \mathrm{pH} 6.5$; Dunphy \& Webster, 1985).

The release of lipopolysaccharides from the Xenorhabdus varieties was monitored in vitro in artificial Galleria larval serum with $(10 \%, \mathrm{v} / \mathrm{v})$ and without a larval serum supplement (Dunphy \& Webster, 1986).

G. mellonella larvae were reared until the sixth instar (Dutky et al., 1962).

Lipopolysaccharide (LPS) release, extraction and fractionation. LPS released by the three Xenorhabdus varieties in vivo and in vitro was monitored using the Limulus amoebocyte lysate assay (Associate of Cape Cod, Inc., Woods Hole, Mass., USA). Serum from Galleria larvae infected with Xenorhabdus had the bacteria removed by centrifugation $\left(10000 \mathrm{~g}, 5 \mathrm{~min}, 10^{\circ} \mathrm{C}\right)$ so that 'infected' serum could be tested for in vivo endotoxin release. LPS was extracted from the three lyophilized Xenorhabdus varieties and from the infected serum using the phenol/water procedure (Westphal \& Jann, 1965), purified by ultracentrifuge-washing $\left(100000 \mathrm{~g}, 3.5 \mathrm{~h}, 4^{\circ} \mathrm{C}\right.$ ) five times with distilled water (Kropinski et al., 1982), lyophilized and stored at $-20^{\circ} \mathrm{C}$.

Lipid A was obtained as a precipitate by boiling $10 \mathrm{mg}$ Xenorhabdus LPS in $1 \mathrm{ml} 1 \%(\mathrm{v} / \mathrm{v})$ acetic acid for $2 \mathrm{~h}$ (Mattsby-Baltzer et al., 1984). The precipitates were centrifuge-washed three times $\left(5000 \mathrm{~g}, 10 \mathrm{~min}, 5^{\circ} \mathrm{C}\right.$ ) in distilled water followed by extraction with chloroform/methanol ( $5: 1, \mathrm{v} / \mathrm{v})$ (Russa et al., 1985).

The water fractions from the initial LPS hydrolysates containing the oligosaccharide portions were centrifuged $\left(100000 \mathrm{~g}, 4 \mathrm{~h}, 4^{\circ} \mathrm{C}\right)$ to remove unhydrolysed LPS and lipid A. The supernatants were lyophilized either directly or after exhaustive dialysis against distilled water. A subsequent amoebocyte lysate assay did not detect endotoxin activity in these fractions.

Total fatty acid extracts from the lipid A of each of the three Xenorhabdus varieties were obtained by hydrolysing $10 \mathrm{mg}$ of each lipid A in $6 \mathrm{ml} 6 \mathrm{M}-\mathrm{HCl}$ at $100^{\circ} \mathrm{C}$ for $2.5 \mathrm{~h}$ followed by alkaline hydrolysis in $4 \mathrm{M}-\mathrm{KOH}$ (Haeffner $e t$ al., 1977), extraction in chloroform and blowing dry under nitrogen gas. The D-glucosamine content of the aqueous phase was determined with an amino acid analyser.

${ }^{32} \mathrm{P}$-labelled $X$. nematophilus subsp. nematophilus var. dutky was obtained by growing the bacteria for $6 \mathrm{~h}$ in 10 litres of LB-broth containing 3.7 $\times 10^{8} \mathrm{~Bq}$ carrier-free [32 P]phosphate. [ $\left.{ }^{32} \mathrm{P}\right] \mathrm{LPS}$ and [ $\left.{ }^{32} \mathrm{P}\right] l i p i d \mathrm{~A}$ were extracted from the bacteria as described above.

LPS extracts were suspended in PBS by vortexing for ten 2 min periods and ultrasonicating for ten $1 \mathrm{~min}$ periods. The carbohydrate fractions were dissolved in PBS. Lipid A and total fatty acid fractions were dissolved in $0.5 \%(\mathrm{v} / \mathrm{v})$ triethylamine in PBS.

Toxicity assay for LPS and its fractions. Toxicity of LPS and its fractions was based on the adhesion of selected bacterial species to the granular cells and plasmatocytes in vitro and on the elevation of larval haemocyte counts in vivo.

Unless otherwise stated, larvae were injected with $10 \mu 1$ of solution containing either $2 \mu 1 \mathrm{LPS}$ or $0 \cdot 2 \mathrm{ng}$ of lipid A or the total fatty acid extract. Control larvae received $10 \mu \mathrm{l}$ PBS with and without $0.5 \%(\mathrm{v} / \mathrm{v})$ triethylamine. Coinjections of LPS, lipid A and total fatty acid extracts with $10 \mathrm{mM}-\mathrm{D}$-glucosamine [routinely detected in enterobacterial LPS (Wollenweber $e t$ al., 1982)] and $N$-acetyl-D-glucosamine [a common sugar associated with bacterial envelopes (Hammond et al., 1984)] and polymyxin B sulphate [which binds to lipid A (Teuber \& Bader, 1976)] were done to ascertain the nature of the binding of these fractions to the haemocytes.

Insects were bled at designated times post-injection following the amputation of a thoracic proleg, and the haemocytes counted on a haemocytometer.

The influence of LPS on the adhesion of selected bacterial species to G. mellonella plasmatocytes and granular cells in vitro was assayed using a modification of the monolayer procedure of Ratcliffe et al. (1984). The prophenoloxidase-activating system, which may be part of the antibacterial response in insects (Leonard et al., 1985), exists in $G$. mellonella (Janssen, 1986). The antimelanizing agent 1-phenyl-2-thiourea $\left(0.25 \mathrm{mg}^{-1}\right)$ was added to the PBS used in these experiments to block phenoloxidase activity; the resulting mixture is referred to as 
modified PBS. The monolayers were incubated in a nitrogen atmosphere so as to further decrease melanin formation and its possible influence on bacterial attachment to haemocytes (Dunn, 1986).

Slides with $100 \mu \mathrm{l}$ modified PBS were inoculated with $100 \mu \mathrm{l}$ haemolymph. The haemocytes were allowed to attach to the substrate for $5 \mathrm{~min}$, then $100 \mu 1$ modified PBS containing 6.2 $\mu \mathrm{g} X$. nematophilus subsp. nematophilus var. dutky LPS was added to the haemocyte suspension and the mixture was incubated for $5 \mathrm{~min}$ at $27^{\circ} \mathrm{C}$ on a platform shaker (100 r.p.m.). Test bacteria (B. subtilis, $P$. vulgaris, $X$. nematophilus subsp. nematophilus var. dutky) in $10 \mu \mathrm{l}$ modified PBS were added to the slides and incubated for $5 \mathrm{~min}$. The haemocyte:bacteria ratio was $1: 10000$. The slides were rinsed free of nonadhering bacteria and haemocytes (the latter consisting entirely of spherulocytes, prohaemocytes and oenocytoids) with modified PBS. The number of bacteria per plasmatocyte and per granular cell, and the percentage of these haemocytes with bacteria, was determined by examining 100 granular cells and plasmatocytes from each of 20 slides under the phase-contrast microscope. Phagocytosis was not measured.

[32P]LPS and [ $\left.{ }^{32} \mathrm{P}\right]$ lipid A binding to mixed haemocyte populations and isolated granular cells was initiated by adding $10 \mu \mathrm{l}$ [32 P]LPS (140000 d.p.m.) or [ ${ }^{32}$ P]lipid A (8000 d.p.m.) to microcentrifuge tubes containing $200 \mu 1$ diluted haemolymph $(1: 3, \mathrm{v} / \mathrm{v}$, with modified PBS) or $200 \mu \mathrm{l}$ modified PBS containing granulocytes. Modified PBS was required to prevent melanization, which enhances LPS binding to the reaction vessels. The optimum incubation time for LPS and lipid A binding was $10 \mathrm{~min}$ at $20^{\circ} \mathrm{C}$. Thereafter, extensive haemocyte lysis occurred with a concomitant decline in LPS and lipid A binding. The haemocytes were centrifuge-washed twice $(10000 \mathrm{~g}$, $1 \mathrm{~min}, 15^{\circ} \mathrm{C}$ ) with modified PBS until no radioactivity was detected in the supernatant. Scintiverse II (1 ml) was added to each microcentrifuge tube followed by vortexing until the haemocyte pellet dispersed. The microcentrifuge tubes were placed into polyethylene scintillation counting vials and counted in a Beckman (LS 380) scintillation counter for 5 min per sample. Control samples consisted of (i) haemolymph in which the haemocytes had been lysed by ultrasonication and the solution converted to serum by centrifugation prior to the addition of the labelled test material, and (ii) intact haemocytes without the addition of labelled material. There was no significant difference between the scintillation counts of the two control groups, and so these groups were pooled and termed 'pooled controls'.

Haemocyte separation. The haemocytes from whole haemolymph were fractionated on a discontinuous Percoll (Sigma) gradient whose concentrations were 9, 17, 23, 29, 31 and 33\% (v/v) in modified PBS (pH 6.5). The osmolality of each Percoll step was maintained with D-glucose at 430 mosm, the osmolality of larval G. mellonella serum. Gradients were formed in $16 \mathrm{ml}$ silanized round-bottomed polystyrene test tubes (Evergreen Scientific) using $1 \mathrm{ml}$ volumes of the gradient solutions. Haemolymph ( $200 \mu \mathrm{l})$ was added to $800 \mu \mathrm{l}$ of $9 \%$ Percoll solution and layered evenly at the $9 / 17$ Percoll interface. The test tubes were centrifuged in a swinging-bucket rotor $(5000 \mathrm{~g}$, $90 \mathrm{~min}, 5^{\circ} \mathrm{C}$ ). Haemocytes at the $29 / 31$ interface consisted of $98 \%$ granular cells with a viability of at least $80 \%$. The granular cells were centrifuge-washed $\left(10000 \mathrm{~g}, 1 \mathrm{~min}, 5^{\circ} \mathrm{C}\right)$ with modified PBS supplemented with D-glucose $\left(12.7 \mathrm{~g}^{-1}\right)$. Granular cell viability averaged $87 \%$. The granular cell fraction was used to determine the effects of $\mathrm{D}-$ glucose and its derivatives on $\left[{ }^{32} \mathrm{P}\right] \mathrm{LPS}$ and $\left[{ }^{32} \mathrm{P}\right]$ lipid $\mathrm{A}$ binding.

SDS-PAGE. The Laemmli (1970) SDS-PAGE system was used in vertical slab gels to separate LPS molecules. The $5 \mathrm{~cm}$ stacking gel and $15 \mathrm{~cm}$ running gel of $4.5 \%$ and $12.5 \%(\mathrm{w} / \mathrm{v})$ acrylamide, respectively, were subjected to $15 \mathrm{~mA}$ per gel. The gels were silver-stained (Tsai \& Frasch, 1982).

Data analysis. Unless otherwise stated, data are expressed as the mean \pm standard error of the mean. Percentages are expressed as the decoded mean of the $2 \arcsin \sqrt{ } p$ transformed data with $95 \%$ confidence limits. Changes in haemocyte counts were analysed using the Mann-Whitney U test (Sokal \& Rohlf, 1969). The level of significance was $P<0.05$.

\section{RESULTS}

The larvae injected with LPS from each of the three $X$. nematophilus subsp. nematophilus varieties had lower total haemocyte levels than did the PBS control larvae within 5 min of injection $(P<0.05)$ (Fig. 1). In LPS-injected larvae this was followed by a rapid increase in number of vacuolated haemocytes to maximum values at 20-35 min post-injection and a lytic decline thereafter. No nodules were detected. Within $1 \mathrm{~h}$ of injection of LPS, fat-body dissociation was observed based on the visual detection of individual fat-body cells and fat-body cell aggregates in the haemolymph of the larvae.

The LPS electrophoretic profiles of the breton and dutky varieties differed in detail from each other, (although both showed the ladder pattern of bands typical of smooth LPS), whereas those of the mexicanus and dutky varieties were identical to each other (not shown). The relative toxicity of the three LPS varieties was tested by injecting LPS into the larvae such that the levels of 3-deoxy-D-manno-octulosonic acid [determined by the thiobarbituric assay of Kharkhanis $e t$ 


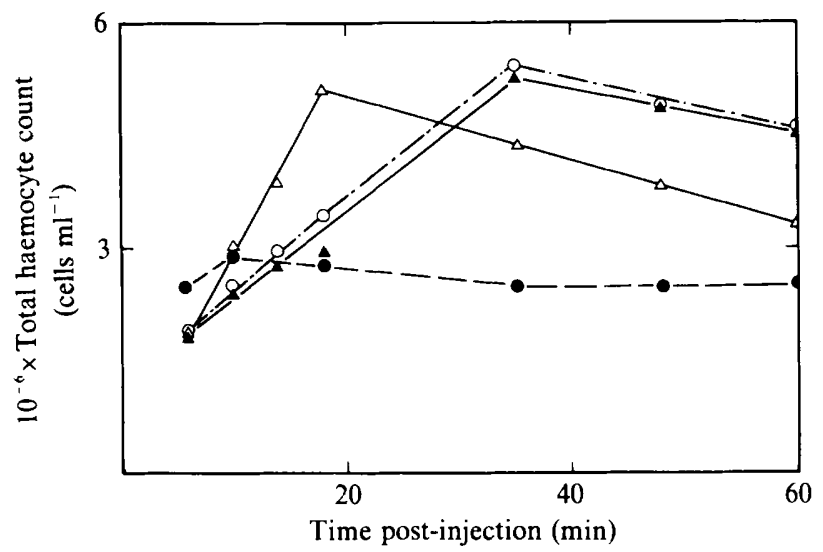

Fig. 1. Changes in total haemocyte counts of larval $G$. mellonella injected with LPS from $X$. nematophilus subsp. nematophilus var. dutky $(\Lambda)$, var. breton $(\triangle)$ and var. mexican $(O)$. Control larvae received PBS (O).

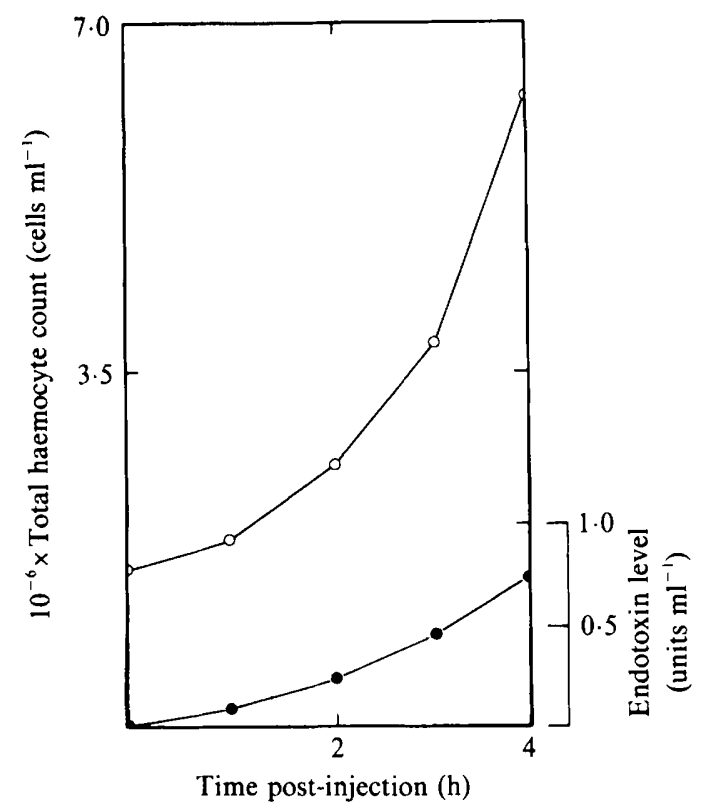

Fig. 2. Changes in total haemocyte counts $(O)$ and endotoxin levels $(O)$ in serum of larval $G$. mellonella following infection with live $X$. nematophilus subsp. nematophilus var. dutky.

al. (1978)] per $10 \mathrm{ml}$ of LPS solution were the same. There was no significant difference in the rate of haemocyte increase between the different LPS varieties (rate $=1.4-1.2 \times 10^{5}$ cells ml $^{-1}$ $\min ^{-1}, P>0.05$ ).

Living or dead bacterial cells of each of the three varieties increased the haemocyte counts. The increase in the number of haemocytes was correlated with the presence of Limulus amoebocyte lysate coagulation factors (Fig. 2). Phenol/water extractions of infected larval serum produced factors which, in addition to coagulating the amoebocyte lysate, also elevated haemocyte counts at a rate not statistically different from that caused by the same amount of LPS from the homologous bacterial variety $(P>0.05)$ (Table 1$)$. The serum extracts and envelope LPS for a given bacterial variety produced identical gel profiles on SDS-PAGE (not shown). Thus, the serum extracts are regarded as being LPS in nature. 
Table 1. Effects of endotoxin cell envelope extracts from varieties of $X$. nematophilus subsp. nematophilus and of larval serum from G. mellonella infected by these bacteria on the increase in total haemocyte counts

\begin{tabular}{|c|c|c|}
\hline $\begin{array}{c}\text { Bacterial } \\
\text { variety }\end{array}$ & Extract source* & $\begin{array}{l}10^{-5} \times \text { Rate of increase } \\
\text { in haemocyte count } \\
\left(\text { cells } \mathrm{ml}^{-1} \mathrm{~min}^{-1}\right) \dagger\end{array}$ \\
\hline dutky & $\begin{array}{l}\text { Cell envelope } \\
\text { Infected larval serum }\end{array}$ & $\begin{array}{l}2 \cdot 3 \pm 0 \cdot 1 \\
2 \cdot 0 \pm 0 \cdot 2\end{array}$ \\
\hline breton & $\begin{array}{l}\text { Cell envelope } \\
\text { Infected larval serum }\end{array}$ & $\begin{array}{l}2 \cdot 5 \pm 0 \cdot 1 \\
2 \cdot 7 \pm 0 \cdot 1\end{array}$ \\
\hline mexican & $\begin{array}{l}\text { Cell envelope } \\
\text { Infected larval serum }\end{array}$ & $\begin{array}{l}3 \cdot 1 \pm 0 \cdot 1 \\
2 \cdot 8 \pm 0 \cdot 1\end{array}$ \\
\hline$-\ddagger$ & Uninfected larval serum & $0 \cdot 0 \pm 0 \cdot 0$ \\
\hline
\end{tabular}

Table 2. Adhesion of selected bacterial species to larval G. mellonella haemocytes in vitro in the presence of $X$. nematophilus subsp. nematophilus var. dutky LPS and antimelanizing agents*

\begin{tabular}{|c|c|c|c|c|c|}
\hline & & Bacteria pe & haemocyteł & Haemocytes w & bacteria $(\%) \S$ \\
\hline Bacterium & Treatment $\dagger$ & Granular cells & Plasmatocytes & Granular cells & Plasmatocytes \\
\hline Bacillus subtilis & PBS & $5 \cdot 0 \pm 0 \cdot 2$ & $1 \cdot 3 \pm 0 \cdot 4$ & $\begin{array}{c}81 \\
(2 \cdot 346-2 \cdot 165)\end{array}$ & $\begin{array}{c}17 \\
(0.976-0.795)\end{array}$ \\
\hline & LPS & $3 \cdot 8 \pm 0 \cdot 4$ & $3 \cdot 8 \pm 0 \cdot 5$ & $\begin{array}{c}40 \\
(1 \cdot 471-1 \cdot 308)\end{array}$ & $\begin{array}{c}52 \\
(1 \cdot 711-1 \cdot 571)\end{array}$ \\
\hline Proteus vulgaris & PBS & $5 \cdot 5 \pm 0 \cdot 5$ & $3 \cdot 0 \pm 0 \cdot 4$ & $\begin{array}{c}94 \\
(2 \cdot 793-2 \cdot 606)\end{array}$ & $\begin{array}{c}70 \\
(2 \cdot 118-1 \cdot 918)\end{array}$ \\
\hline & LPS & $2 \cdot 1 \pm 0 \cdot 4$ & $1 \cdot 3 \pm 0 \cdot 0$ & $\begin{array}{c}13 \\
(0 \cdot 850-0 \cdot 676)\end{array}$ & $\begin{array}{c}21 \\
(1.047-0.850)\end{array}$ \\
\hline $\begin{array}{l}X . \text { nematophilus } \\
\text { subsp. nematophilus }\end{array}$ & PBS & $1 \cdot 1 \pm 0.4$ & $1.4 \pm 0.4$ & $\begin{array}{c}11 \\
(0.795-0.574)\end{array}$ & $\begin{array}{c}18 \\
(0.952-0.823)\end{array}$ \\
\hline var. dutky & LPS & $1.5 \pm 0.4$ & $2.8 \pm 0.4$ & $\begin{array}{c}8 \\
(0 \cdot 676-0 \cdot 495)\end{array}$ & $\begin{array}{c}51 \\
(1 \cdot 713-1 \cdot 568)\end{array}$ \\
\hline
\end{tabular}

* Nitrogen atmosphere and PBS containing trace levels of phenylthiourea.

$\dagger$ PBS, Phosphate-buffered saline, pH 6.5, with trace amounts of phenylthiourea; LPS, lipopolysaccharide (6.2 2 g per $100 \mu \mathrm{l}$ PBS).

$\ddagger$ Means \pm standard error of the mean; $n=20$ samples ( 100 haemocytes of each type examined per sample).

$\S$ Means (with $95 \%$ confidence limits of 2 arcsin $\checkmark p$ transformed data); $n=20$ samples ( 100 haemocytes of each type examined per sample).

Incubating $X$. nematophilus subsp. nematophilus var. dutky with synthetic larval serum alone or synthetic larval serum with either washed intact or lysed haemocytes failed to elicit detectable amounts of endotoxin. However, in synthetic larval serum supplemented with larval serum, substantial endotoxin activity was detected within $4 \mathrm{~h}$ of inoculating the medium.

LPS influenced bacterial adhesion to $G$. mellonella plasmatocytes and granular cells in a manner that varied with the bacterial test species and the haemocyte type (Table 2). In general, LPS from the bacterial envelope of the dutky variety decreased bacterial adhesion to the granular cells and increased contact with the plasmatocytes $(P<0.05)$. LPS decreased adhesion of $P$. vulgaris to both types of haemocytes.

The toxicity of LPS from the three Xenorhabdus varieties was decreased by polymyxin B sulphate. LPS from the $d u t k y$ variety was neutralized when the LPS : polymyxin B sulphate ratio was $51: 1$ (Fig. 3). The amount of antibiotic required for neutralization varied with the LPS 


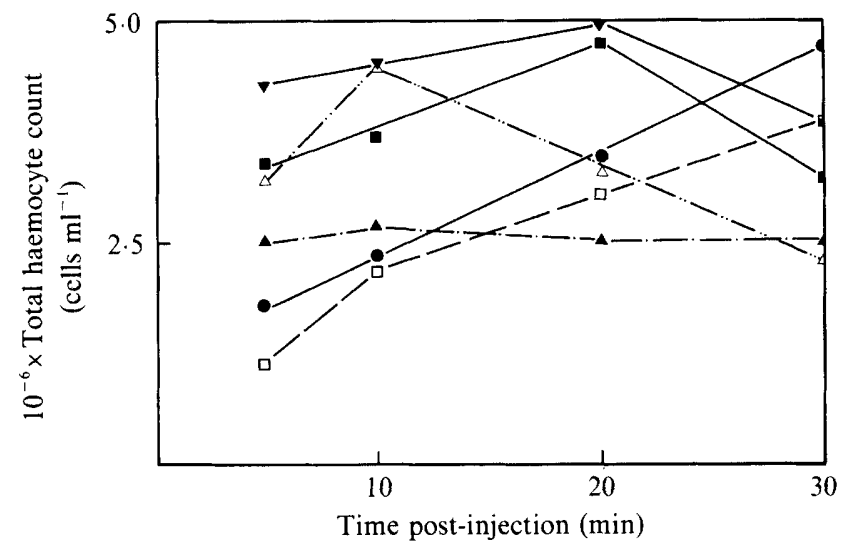

Fig. 3. Effects on total haemocyte counts of injecting $X$. nematophilus subsp. nematophilus var. dutky LPS with increasing concentration of polymyxin B sulphate into larval G. mellonella. LPS (167 ng per larva) plus polymyxin B sulphate at $0(\bigcirc), 3.3(\triangle), 16.7(\square)$ and $33.3(\square)$ ng per larva; polymyxin B sulphate alone at $33 \cdot 3 \mathrm{ng}$ per larva $(\boldsymbol{\nabla})$; $\operatorname{PBS}(\mathbf{\Delta})$.

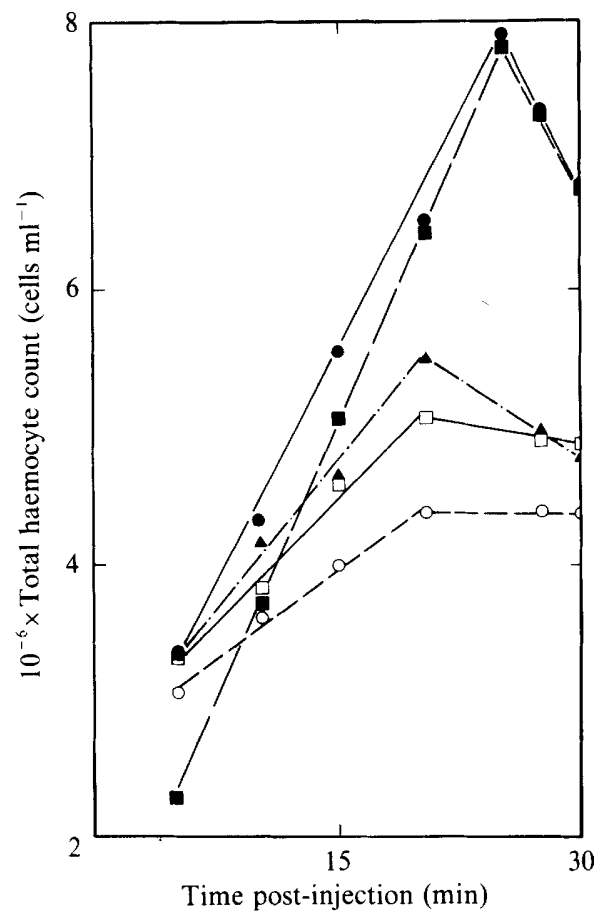

Fig. 4. Changes in larval $G$. mellonella total haemocyte counts in response to $X$. nematophilus subsp. nematophilus var. dutky LPS ( $\square$ ), lipid A (O), total oligosaccharides from LPS (O), and PBS with ( $\mathbf{)})$ and without $(\square) 0.5 \%$ triethylamine.

source and was stoichiometrically related to the LPS concentration. Increasing the concentration of polymyxin B sulphate for a given amount of LPS of the dutky variety increased the elevation of the haemocyte counts. Antibiotic alone elevated the haemocyte counts. Mixing LPS from the three Xenorhabdus varieties with excess polymyxin B sulphate followed by exhaustive dialysis against PBS to remove unbound antibiotic abrogated LPS toxicity.

Injecting LPS and the corresponding amounts of lipid A and total oligosaccharide from the LPS showed that only the carbohydrate fraction lowered haemocyte counts below the control levels (Fig. 4). Nodules were detected in the haemocoel in close proximity to the injection site in 
Table 3. Binding of X. nematophilus subsp. nematophilus var. dutky $\left[{ }^{32} P\right] L P S$ to larval $G$. mellonella haemocytes in vitro, in the presence of selected carbohydrates

\section{Carbohydrate}

(10 mM)

PBS $\dagger$
D-Glucose
D-Glucosamine
$N$-Acetyl-D-glucosamine
3-Deoxy-D-manno-octulosonic acid
D-Galactose
D-Galactosamine
$N$-Acetyl-D-galactosamine
D-Mannose
D-Fucose
D-Trehalose
Pooled controls

$$
\begin{gathered}
\begin{array}{c}
\text { Bound LPS } \\
\text { (d.p.m.)* }
\end{array} \\
460 \pm 53 \\
452 \pm 49 \\
624 \pm 66 \\
365 \pm 19 \\
405 \pm 27 \\
447 \pm 34 \\
582 \pm 21 \\
357 \pm 20 \\
468 \pm 15 \\
846 \pm 11 \\
1751 \pm 23 \\
27 \pm 03
\end{gathered}
$$

* Means \pm standard error of the mean; $n=10$ samples.

$\dagger$ Trace level of phenylthiourea present, to prevent melanization effects.

Table 4. Binding of $\left[{ }^{32} P\right] L P S$ and $\left[{ }^{32} P\right]$ lipid $A$ of $X$. nematophilus subsp. nematophilus var. dutky to isolated $G$. mellonella granular cells in the presence of selected carbohydrates

$\begin{array}{lcc}\begin{array}{c}\text { Carbohydrate } \\ (10 \mathrm{~mm})\end{array} & \begin{array}{c}\text { Bound LPS } \\ (\text { d.p.m.) }\end{array} & \begin{array}{c}\text { Bound lipid A } \\ \text { (d.p.m.) }\end{array} \\ \text { PBS } \dagger & 597 \pm 26 & 275 \pm 10 \\ \text { D-Glucose } & 603 \pm 31 & 283 \pm 12 \\ \text { D-Glucosamine } & 851 \pm 12 & 178 \pm 05 \\ N \text {-Acetyl-D-glucosamine } & 254 \pm 17 & 137 \pm 12 \\ \text { * Means } \pm \text { standard error of the mean; } n=10 \text { samples. } \\ \text { † Trace level of phenylthiourea present, to prevent melanization. }\end{array}$

larvae receiving the oligosaccharide. Lipid $\mathrm{A}$ induced a rapid rise in haemocyte numbers comparable to that caused by LPS.

Analysis for ninhydrin-positive compounds detected D-glucosamine in lipid A at approximately $22 \%(\mathrm{w} / \mathrm{w})$. Co-injection of $10 \mathrm{~mm}-\mathrm{D}$-glucosamine with lipid A prevented an increase in haemocyte counts. Polymyxin B sulphate neutralized lipid A activity when used in a 2:1 ratio. Both lipid A and LPS, at $0.5 \mathrm{mg}$ per larva and $5 \mathrm{mg}$ per larva, respectively, induced larval swelling, haemolymph coagulation and extensive fat-body destruction. These effects were blocked when the toxins were co-injected with $10 \mathrm{mM}$-D-glucosamine.

To determine the stereospecific nature of the interaction between lipid $\mathrm{A}$ and the haemocytes, larvae were co-injected with lipid A plus $10 \mathrm{mM}$-D-glucose, D-glucosamine, $N$-acetyl-Dglucosamine, D-galactose, D-galactosamine or $\mathrm{N}$-acetyl-D-galactosamine. D-Glucosamine, $\mathrm{N}$ acetyl-D-glucosamine, D-galactosamine and $N$-acetyl-D-galactosamine each neutralized the lipid A haemocytotoxin activity to a similar extent.

Binding of $\left.{ }^{32} \mathrm{P}\right] \mathrm{LPS}$ from $X$. nematophilus subsp. nematophilus var. dutky to G. mellonella haemocytes was diminished by $N$-acetyl-D-galactosamine and $N$-acetyl-D-glucosamine and enhanced by D-glucosamine and D-galactosamine (Table 3) even though the latter two sugars prevented LPS-induced haemocyte damage in vivo. Similar results were obtained with isolated granular cells (Table 4). Both D-fucose and D-trehalose substantially increased LPS binding to mixed haemocytes (Table 3). Both D-glucosamine and $N$-acetyl-D-glucosamine diminished lipid A binding to the granular cells (Table 4).

The type of D-glucose derivative and its concentration influenced the binding of [ $\left.{ }^{32} \mathrm{P}\right] \mathrm{LPS}$ and [ $\left.{ }^{32} \mathrm{P}\right]$ lipid A to mixed haemocytes. Both D-glucosamine and $N$-acetyl-D-glucosamine decreased 


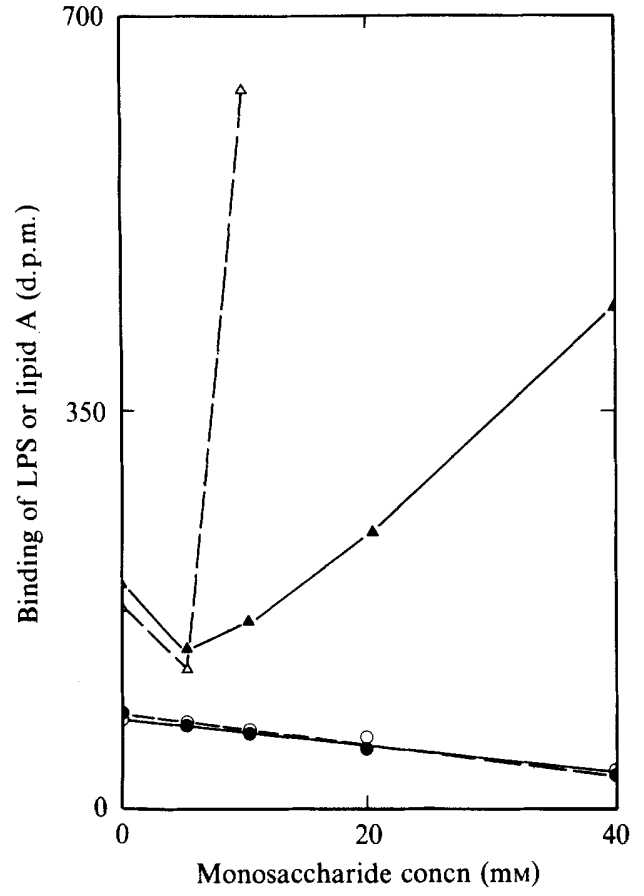

Fig. 5

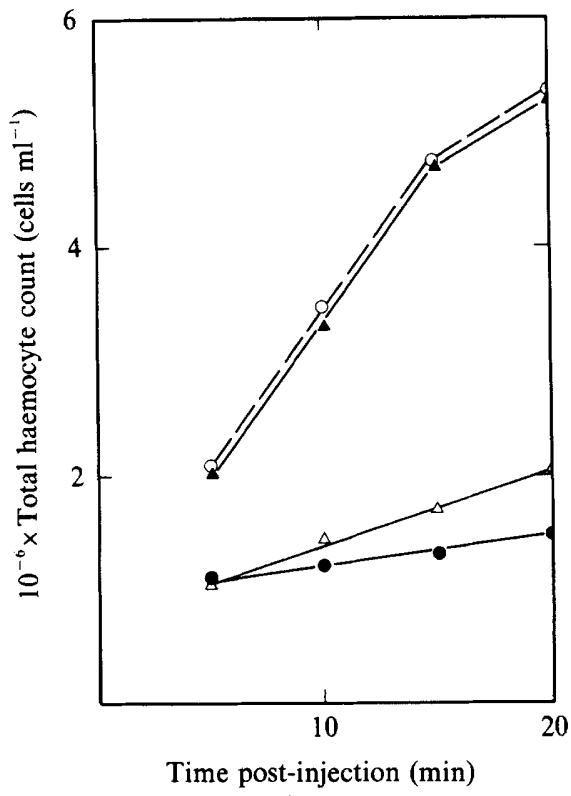

Fig. 6

Fig. 5. Binding of $X$. nematophilus subsp. nematophilus var. dutky [ $\left.{ }^{32} \mathrm{P}\right] \mathrm{LPS}$ to larval $G$. mellonella haemocytes in the presence of $N$-acetyl-D-glucosamine $(\Delta)$ and D-glucosamine $(\triangle)$, and binding of [32 P]lipid $\mathrm{A}$ in the presence of $N$-acetyl-D-glucosamine $(\mathrm{O})$ and D-glucosamine (O).

Fig. 6. Changes in larval $G$. mellonella total haemocyte counts in response to injections of lipid $A(A)$, total fatty acid extracts of lipid A (O), $0.5 \%$ triethylamine in PBS $(\triangle)$ and PBS (O). Lipid A and its fatty acids were obtained from $X$. nematophilus subsp. nematophilus var. dutky LPS.

the binding of lipid A $(P<0.05)$ over the range of monosaccharide concentrations tested (Fig. 5). At $5 \mathrm{~mm}$ both sugars decreased LPS binding, but thereafter binding increased, with $\mathrm{D}-$ glucosamine having the greatest effect.

Injecting larvae with up to $100 \mu \mathrm{g}$ phosphoethanolamine, ethanolamine and D-glucosaminylD-glucosamine, compounds associated with enterobacterial lipid A, did not elevate haemocyte counts or cause gross toxicity symptoms in the insects. Injecting larvae with the total fatty acid extracts from the lipid A of LPS from the dutky variety, and with lipid A providing a corresponding amount of fatty acids, elevated haemocyte counts (Fig. 6) at rates which were not statistically different $(P>0.05)$. The fatty acid effect could not be offset by either $\mathrm{D}$-glucosamine or $\mathrm{N}$-acetyl-D-glucosamine.

\section{DISCUSSION}

In the present study the haemocytotoxin in $G$. mellonella infected with $X$. nematophilus is LPS. The toxin in infected larval serum and in the phenol/water extract of the larval serum, like LPS from the bacterial cell envelope, induced Limulus amoebocyte coagulation. The serum extract and bacterial cell envelope LPS of homologous varieties induced similar rates of haemocyte damage when injected into the larvae, and the electrophoretic profiles of the two extracts were identical. The correlation of LPS release from varieties of $X$. nematophilus and haemocyte damage and re-emergence of $X$. nematophilus into the haemolymph (see Dunphy \& Webster, 1984) establishes LPS as a component of the virulence mechanisms of $X$. nematophilus. 
LPS was released from both living and dead $X$. nematophilus, but only when the bacteria were exposed to humoral factors. This would explain the previously reported absence of toxins in Xenorhabdus spent media devoid of larval serum (Boemare et al., 1982; Dunphy \& Webster, 1986). The reported absence of toxic activity in media supplemented with larval serum (Dunphy \& Webster, 1986) may reflect the low levels of toxin production, the use of extensive gravity to remove bacteria from the medium and the use of relatively insensitive assay parameters, such as silk production and larval weight. Dunphy $\&$ Webster (1984) reported that living bacteria were not required in order for the toxin to be released. Although G. mellonella serum is believed to modify the envelope of $X$. nematophilus (Dunphy \& Webster, 1984) it is not known how this relates to LPS release.

Short-term exposure of haemocyte monolayers to the dutky variety of LPS generally decreased adhesion of the test bacteria to the granular cells and enhanced bacterial contact with the plasmatocytes. Ratcliffe et al. (1984) reported that Escherichia coli O.55:B5 endotoxin enhanced the phagocytosis of Bacillus cereus by $G$. mellonella plasmatocytes and granular cells without activating the prophenoloxidase system. Although phenoloxidase activated by $\beta$-1,3-glucans and endotoxin may have a role to play in self/non-self recognition by arthropod haemocytes (Söderhall, 1981; Söderhall \& Häll, 1984) endotoxin-triggered phenoloxidase does not occur in insects (Ashida et al., 1983; Leonard et al., 1985). However, to minimize any possible involvement of phenoloxidase in the present study, phenylthiourea and nitrogen gas were used to prevent phenoloxidase activation. Thus, larval G. mellonella haemocytes may initiate non-self responses by means of cell-surface lectins binding to selected carbohydrates associated with LPS. The ability of amino sugars to prevent haemocyte damage and to influence LPS and lipid A binding supports this contention. Enhancement of plasmatocyte activity by $X$. nematophilus LPS may represent either direct activation by LPS binding and/or indirect activation by granular cell discharge products, other than phenoloxidase, induced by LPS binding to the granular cells, perhaps in a cooperative manner as proposed by Ratcliffe et al. (1984). Haemocyte surface lectins and factors affecting plasmatocyte activity have been well documented for insects (Dunn, 1986).

Shigella flexneri LPS initiated nodulation in G. mellonella (Schwabel \& Boush, 1971) and Serratia marcescens LPS and E. coli LPS triggered diffuse nodulation in Schistocerca gregaria and Locusta migratoria (Gunnarsson \& Lackie, 1985). Nodulation may have occurred in G. mellonella injected with $X$. nematophilus LPS because the carbohydrate portion of the LPS induced nodulation. However, the survival of such nodules would be in doubt due to the haemocytotoxin activity of the LPS.

The observations that (1) the LPS gel profiles of the breton and dutky varieties differed, (2) injecting LPS samples containing the same concentration of 3-deoxy-D-manno-octulosonic acid produced comparable effects and (3) lipid A binding of polymyxin B sulphate neutralized LPS toxicity suggests that lipid A was the toxic moiety. This was confirmed by injecting lipid A into the larvae and neutralizing haemocyte damage, larval death and haemolymph coagulation with polymyxin B sulphate and selected amino sugars. Although LPS has been reported to influence haemocyte activity in arthropods (Kurstak et al., 1969; Newman \& Feng, 1982; Goldenberg \& Greenberg, 1984; Gunnarsson \& Lackie, 1985), induction of immunity in both insect (Chadwick \& Vilk, 1969) and non-insect arthropods (Evans et al., 1969), and the induction of antibacterial proteins in mixed haemocyte and fat-body cultures (DeVerno et al., 1984), the active moiety of LPS has in most cases not been identified. Chadwick \& Vilk (1969) reported that the oligosaccharide moieties of LPS induced immunity in $G$. mellonella, and Proctor \& Textor (1985) discovered that the lipid A portion of E. coli LPS induced Limulus amoebocyte lysate coagulation. The present study is the first in insects to relate LPS toxicity to lipid A. It is known that most LPS toxic activity for mammals resides with the lipid A portion of the molecule (Galanos et al., 1977). Moreover, as with Salmonella minnesota (Wollenweber et al., 1982) and Shigella flexneri (Mattsby-Baltzer et al., 1984), the fatty acids of $X$. nematophilus lipid A are responsible for endotoxin expression.

The haemocyte toxicity of LPS and lipid A was blocked with $\mathrm{N}$-acetylated and non-acetylated amino sugars, suggesting that LPS, in part, binds to haemocytes by means of the glucosaminyl 
residue of lipid A. This was confirmed with the binding of [ $\left.{ }^{32} \mathrm{P}\right]$ LPS and [32P]lipid $\mathrm{A}$ to mixed haemocytes and purified granular cells.

The use of ${ }^{32}$ P-labelled LPS and lipid A, and of amino sugar inhibition of LPS and lipid A binding, produced unexpected results. Both D-glucosamine and $N$-acetyl-D-glucosamine decreased lipid A binding as the concentrations of the monosaccharides increased. However, the binding of [ ${ }^{32}$ P]LPS initially decreased and then increased with increasing monosaccharide concentration. The latter occurred even though in vivo toxic activity was suppressed. The binding profile of [ $\left.{ }^{32} \mathrm{P}\right]$ LPS to the granular cells in the presence of the inhibitory sugars suggests that two events occurred. At low amino sugar concentrations LPS binding would be impaired due, in part, to the inhibition of lipid A binding. The enhanced binding of LPS once the concentration of the amino sugar exceeded a critical threshold implies that the granular cells had been altered and become more adhesive for LPS. Localized granulocyte degranulation that entraps foreign particles in a coagulum is known to occur in $G$. mellonella in response to non-self recognition (Ratcliffe \& Rowley, 1979). Lackie (1979) proposed that non-self haemocyte responses would occur once a critical threshold of difference was exceeded. The present data support this. The decrease in lipid A binding may represent amino sugars blocking receptors and/or granular cells coagulum induced by the amino sugars either masking haemocyte receptors and/or creating an environment unfavourable to hydrophobic lipid A binding.

Both D-fucose and D-trehalose augmented the binding of [ ${ }^{32}$ P]LPS to the haemocytes. Fucose generally suppresses the adhesion of micro-organisms to larval haemocytes (Dunphy et al., 1986). The present result may reflect the use of simple molecules as opposed to the complex interaction of living micro-organisms with the sugars and the haemocytes. Analysis of bacterial adherence to eukaryotic cells may be complicated by bacterial surface changes (Smith, 1977) and by metabolism or modification of the monosaccharides used in sugar inhibition studies (McEachran \& Irvin, 1985). The trehalose effect was unexpected because trehalose is a major haemolymph sugar in G. mellonella (Wyatt \& Kalf, 1956) and so would be expected to be neutral in the binding of LPS to the haemocytes.

It is concluded that $X$. nematophilus releases LPS into larval G. mellonella haemolymph as a result of the undefined interaction between the bacterial envelope and larval humoral factors. LPS acts as a haemocytotoxin and may also be responsible for fat-body dissociation. Although the carbohydrate portion of the LPS binds to the haemocytes, it is the fatty acids of the lipid A moiety that express endotoxin activity. Lipid A binds to the haemocytes by means of Dglucosaminyl residues to lectin-like molecules on the surfaces of the granulocytes.

The authors thank Mr A. Syed (Simon Fraser University Insectary) for supplying the insects, Ms A. Erdman for advice with the use of [ $\left.{ }^{32} \mathrm{P}\right]$ phosphate and Dr J. Chadwick (Queen's University, Kingston, Canada) for the Proteus vulgaris culture and consultation. This research was supported by grants from the Natural Sciences and Engineering Research Council of Canada and the Science Council of British Columbia.

\section{REFERENCES}

AKHURST, R. J. (1980). Morphological and functional dimorphism in Xenorhabdus spp., bacteria symbiotically associated with the insect pathogenic nematodes Neoaplectana and Heterorhabditis. Journal of General Microbiology 121, 303-309.

Ashida, M., IshizaKI, Y. \& IWAHANA, H. (1983). Activation of prophenoloxidase by bacterial cell walls or $\beta$-1,3-glucans in plasma of the silkworm Bombyx mori. Biochemical and Biophysical Research Communications 113, 562-568.

BertanI, G. (1951). Studies on lysogenesis. I. The model of phage liberation by lysogenic Escherichia coli. Journal of Bacteriology 62, 293-300.

Boemare, N., Laumond, C. \& LuCiani, J. (1982). Mise en évidence d'une toxicogenèse provoquée par le nématode axenique entomophage Neoaplectana car- pocapsae Weiser chez l'insecte axenique Galleria mellonella L. Comptes Rendus de l'Académie des Sciences 295, 543-546.

Chadwick, J. S. \& VILK, E. (1969). Endotoxins from several bacterial species as immunizing agents against Pseudomonas aeruginosa in Galleria mellonella. Journal of Invertebrate Pathology 13, 410-415.

DeVerno, P. J., Chadwick, J. S., Aston, W. P. \& DUNPHY, G. B. (1984). The in vitro generation of an antibacterial activity from the fat body and hemolymph of non-immunized larvae of Galleria mellonella. Developmental and Comparative Immunology $\mathbf{8}$, 537-546.

DunN, P. E. (1986). Biochemical aspects of insect immunology. Annual Review of Entomology 31, 321339. 
DUNPHY, G. B. \& WEBSTER, J. M. (1984). Interaction of Xenorhabdus nematophilus subsp. nematophilus with the haemolymph of Galleria mellonella. Journal of Insect Physiology 30, 883-889.

DUNPHY, G. B. \& WEBSTER, J. M. (1985). Influence of Steinernema feltiae (Filipjev) Wouts, Mracek, Gerdin and Bedding DD136 strain on the humoral and haemocytic responses of Galleria mellonella (L.) larvae to selected bacteria. Parasitology 91, 369-380.

DUNPHY, G. B. \& WEBSTER, J. M. (1986). Influence of the Mexican strain of Steinernema feltiae and its associated bacterium Xenorhabdus nematophilus on Galleria mellonella. Journal of Parasitology 72, 130135.

DUNPHY, G. B., Morton, D. B., Kropinski, A. \& ChaDwick, J. M. (1986). Pathogenicity of lipopolysaccharide mutants of Pseudomonas aeruginosa for larvae of Galleria mellonella: bacterial properties associated with virulence. Journal of Invertebrate Pathology 47, 48-55.

DutKy, S. R., Thompson, J. V. \& Cantwell, G. E. (1962). A technique for mass rearing of the greater wax moth (Lepidoptera: Galleridae). Proceedings of the Entomological Society of Washington 64, 56-58.

Evans, E. E., Weinheimer, P. F., Painter, B., Acton, R. T. \& Evans, M. L. (1969). Secondary and tertiary responses of the induced bactericidin from the West Indian spiny lobster, Panulirus argus. Journal of Bacteriology 98, 943-946.

Galanos, C., Lüderitz, O., RietsChel, E.-T. \& WESTPHAL, O. (1977). Newer aspects of the chemistry and biology of bacterial lipopolysaccharides with special reference to their lipid A components. In Biochemistry of Lipids II (International Review of Biochemistry vol. 14), pp. 239-335. Edited by T. W. Goodwin. Baltimore: University Park Press.

Goldenberg, P. Z. \& GreenberG, A. H. (1984). Activation of lobster hemocytes for phagocytosis. Journal of Invertebrate Pathology 43, 77-88.

GunNarsson, S. G. S. \& Lackie, A. M. (1985). Hemocytic aggregation in Schistocerca gregaria and Periplaneta americana as a response to injected substances of microbial origin. Journal of Invertebrate Pathology 46, 312-319.

Haeffner, N., Chaby, R. \& Szabo, L. (1977). Identification of 2-methyl-3-hydroxydecanoic and 2methyl-3-hydroxytetradecanoic acids in the 'lipid X' fraction of Bordetella pertussis endotoxin. European Journal of Biochemistry 77, 535-544.

HAMmond, S. M., LAmberT, P. A. \& Rycroft, A. N. (1984). The Bacterial Cell Surface, pp. 1-28. Washington, DC: Kapitan Szabo Publishers.

Horohov, D. W. \& DuNN, P. E. (1984). Role of hemocytotoxins in the pathogenicity of Pseudomonas aeruginosa in larvae of the tobacco hornworm, Manduca sexta. Journal of Invertebrate Pathology 43, 297-298.

JANSSEN, K. (1986). Investigation of the prophenoloxidase activating system in Galleria mellonella. Developmental and Comparative Immunology 10, 624.

KAMIONEK, M. (1975). Effect of heat-killed cells of Achromobacter nematophilus Poinar et Thomas, and the fraction (endotoxin) isolated from them on Galleria mellonella L. caterpillars. Bulletin de Académie Polonaise des Sciences 23, 277-281.

Kharkhanis, Y. D., Zeltner, J. Y., Jackson, J. J. \&
CARLo, D. J. (1978). A new and improved microassay to determine 2-keto-3-deoxyoctonate in lipopolysaccharide of Gram-negative bacteria. Analytical Biochemistry 85, 595-601.

KropinSKI, A. M., KuZIO, J., ANGUS, B. L. \& HANCOCK, R. E. W. (1982). Chemical and chromatographic analysis of lipopolysaccharide from an antibiotic-supersusceptible mutant of Pseudomonas aeruginosa. Antimicrobial Agents and Chemotherapy 21, 310-319.

Kurstak, E., Gorging, I. \& Vega, C. (1969). Cellular defence in an arthropod in response to infection with a Salmonella typhimurium strain. Antonie van Leeuwenhoek 35, 45-51.

LACKIE, A. M. (1979). Cellular recognition of foreignness in two insect species, the American cockroach and the desert locust. Immunology 36, 909-914.

LAEMMLI, U. K. (1970). Cleavage of structural proteins during the assembly of the head of bacteriophage T4. Nature, London 227, 680-685.

Leonard, C., Ratcliffe, N. A. \& Rowley, A. F. (1985). The role of prophenoloxidase activation in non-self recognition and phagocytosis by insect blood cells. Journal of Insect Physiology 31, 789799.

LYSENKO, O. (1976). Chitinase of Serratia marcescens and its toxicity to insects. Journal of Invertebrate Pathology 27, 385-386.

McEachran, D. W. \& IRvin, R. T. (1985). Adhesion of Pseudomonas aeruginosa to human buccal epithelial cells: evidence for two classes of receptors. Canadian Journal of Microbiology 31, 563-569.

Mattsby-Baltzer, I., Gernski, P. \& Alving, C. R. (1984). Heterogeneity of lipid A : comparison of lipid A types from different Gram-negative bacteria. Journal of Bacteriology 159, 900-904.

Newman, M. C. \& FenG, S. Y. (1982). Susceptibility and resistance of the rock crab, Cancer irroratus, to natural and experimental bacterial infection. Journal of Invertebrate Pathology 40, 75-88.

Polnar, G. O., JR \& Himsworth, P. T. (1967). Neoaplectana parasitism of larvae of the greater wax moth, Galleria mellonella. Journal of Invertebrate Pathology 9, 241-246.

Proctor, R. A. \& TeXtor, J. A. (1985). Activation and inhibition of Limulus amebocyte lysate coagulation by chemically defined substructures of lipid A. Infection and Immunity 49, 286-290.

Ratcliffe, N. A. \& Rowley, A. F. (1979). Role of hemocytes in defenses against biological agents. In Insect Hemocytes, Development, Form, Functions and Techniques, pp. 331-414. Edited by A. P. Gupta. New York: Cambridge University Press.

Ratcliffe, N. A. \& Walters, J. B. (1983). Studies on the in vivo cellular reactions of insects: clearance of pathogenic and non-pathogenic bacteria in Galleria mellonella larvae. Journal of Insect Physiology 29, 407-415.

Ratcliffe, N. A., Leonard, C. \& Rowley, A. F. (1984). Prophenoloxidase activation: nonself recognition and cell cooperation in insect immunity. Science 226, 557-559.

RuSSA, R., LÜDERITZ, O. \& RIETSCHEL, E.-T. (1985). Structural analysis of lipid A from lipopolysaccharides of nodulating and non-nodulating Rhizobium trifolii. Archives of Microbiology 141, 284-289. 
SCHWABEL, C. P. \& Boush, G. M. (1971). Clearance of ${ }^{51} \mathrm{Cr}$-labelled endotoxin from hemolymph of actively immunized Galleria mellonella. Journal of Invertebrate Pathology 18, 85-88.

SERYCZYNSKA, H. \& KAMIONEK, M. (1977). Stimulation of the phagocyte cells of Galleria mellonella $\mathrm{L}$. by microorganisms. Bulletin de Académie Polonaise des Sciences 25, 173-176.

SMITH, H. (1977). Microbial surfaces in relation to pathogenicity. Bacteriological Reviews 41, 475-500.

SöDERHALL, K. (1981). Fungal cell wall beta-1,3glucans inducing clotting and phenoloxidase attachment to foreign surfaces of crayfish hemocyte lysate. Developmental and Comparative Immunology 5, 565573.

SöDERHALl, K. \& HÄLL, L. (1984). Lipopolysaccharide-induced activation of prophenoloxidase activating system in crayfish haemocyte lysate. Biochimica et biophysica acta 797, 99-104.

SOKAL, R. R. \& ROHLF, F. J. (1969). Biometry, pp. 380387. San Francisco: W. H. Freeman.

TEUBER, M. \& BADER, J. (1976). Action of polymyxin B on bacterial membranes. Archives of Microbiology 109, 51-58.

TSaI, C.-M. \& Frasch, C. E. (1982). A sensitive silver stain for detecting lipopolysaccharides in polyacrylamide gels. Analytical Biochemistry 119, 115-119.

Walters, J. B. \& RatCliffe, N. A. (1983). Studies on the in vivo cellular reactions of insects: fate of pathogenic and non-pathogenic bacteria in Galleria mellonella nodules. Journal of Insect Physiology 29, 417-424.

WestPhal, O. \& JANN, K. (1965). Bacterial lipopolysaccharides. Extraction with phenol-water and further applications of the procedure. Methods in Carbohydrate Chemistry 5, 83-91.

WOLlENWEBER, H.-W., BROADY, K. W., LÜDERITZ, O. \& RIETSCHEL, E.-T. (1982). The chemical structure of lipid A. Demonstration of amide-linked 3-acyloxyacyl residues in Salmonella minnesota $\operatorname{Re}$ lipopolysaccharide. European Journal of Biochemistry 124, 191-198.

WyatT, G. R. \& Kalf, G. F. (1956). Trehalose in insects. Federation Proceedings 15, 388. 